\title{
THE CLASSICAL ASSOCIATION
}

The Classical Association (based in the UK) has a worldwide membership and is open to all who value the study of the languages, literature and civilisations of ancient Greece and Rome. It creates opportunities for friendly exchange and cooperation among classicists, encourages scholarship through its journals and other publications, and supports classics in schools and universities. Every year it holds an annual conference, and it sponsors branches all over the country which put on programmes of lectures and other activities.

The Classical Association has about 3,500 members. Members receive two newsletters, two issues of Omnibus and the Presidential Address each year. They may also subscribe at substantially reduced cost to the Classical Association journals, The Classical Quarterly, The Classical Review and Greece \& Rome. The Fournal of Classics Teaching is freely available online.

For more information and a membership application form please contact the Secretary, The Classical Association, Cardinal Point, Park Road, Rickmansworth, WD3 1RE, UK (tel. +44 (0)7926 632598, e-mail: office@classicalassociation.org). The Secretary can also give information about the reduced journal subscription rates, and about the Association's other occasional publications.

\section{THE CLASSICAL QUARTERLY}

The Classical Quarterly has a reputation for publishing the highest quality classical scholarship for over 100 years. It publishes research papers and short notes in the fields of language, literature, history and philosophy. Two substantial issues of The Classical Quarterly appear each year, normally in May and December. Given the quality and depth of the articles published in The Classical Quarterly, any serious classical library needs to have a copy on its shelves.

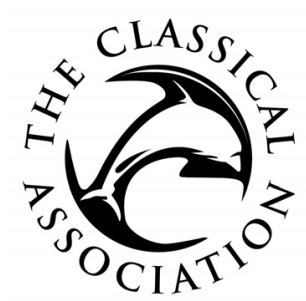

1903

This journal issue has been printed on FSC-certified paper and cover board.

FSC is an independent, non-governmental, not-for-profit organization established to promote the responsible management of the world's forests.

Please see www.fsc.org for information. 


\section{Cambridge Core}

For further information about this journal please go to the journal web site at: cambridgeorg/cag $\sqrt{2} \underset{\text { Maper from }}{\text { MIX }}$ FSC responsible sources Fumwsc.ng FSC $^{\circledR} \mathrm{C007785}$

\section{CAMBRIDGE UNIVERSITY PRESS}

